\title{
Upper Limb Surgeries under Brachial Plexus Block Using Infusion of Dexmedetomidine or Propofol for Monitored Anaesthesia Care - A Comparative Study
}

\author{
Kumkum Gupta ${ }^{1}$, Salony Agarwal' ${ }^{2}$, Prashant K Gupta ${ }^{3}$, Abhishake Kumar ${ }^{4}$, PavitraKalra ${ }^{5}$, Kopal Gupta $^{6}$ \\ ${ }^{1}$ Professor, Department of Anaesthesiology and Critical care, Subharti Medical College, Swami Vivekanand Subharti University, NH-58 Bye Pass Road, \\ Meerut-UP, India, ${ }^{2}$ Associate Professor, Department of Anaesthesiology and Critical care, Subharti Medical College, Swami Vivekanand Subharti \\ University, NH-58 Bye Pass Road, Meerut-UP, India, ${ }^{3}$ Director \&Professor, Department of Radio diagnosis and Imaging, Subharti Medical College, Swami \\ Vivekanand Subharti University, NH-58 Bye Pass Road, Meerut-UP, India, ${ }^{4}$ Professor. Department of Anaesthesiology and Critical care, Subharti Medical \\ College, Swami Vivekanand Subharti University, NH-58 Bye Pass Road, Meerut-UP, India, ${ }^{5}$ Resident, Department of Anaesthesiology and Critical care, \\ Subharti Medical College, Swami Vivekanand Subharti University, NH-58 Bye Pass Road, Meerut-UP, India, ${ }^{6}$ Resident, Department of Anaesthesiology \\ and Critical care Subharti Medical College, Swami Vivekanand Subharti University, NH-58 Bye Pass Road, Meerut-UP, India.
}

\section{Abstract}

Background: Brachial plexus block is widely used for upper limb surgeries but intraoperatively, patients remain awake and anxious. This study has compared the intraoperative sedation of dexmedetomidine infusion versus propofol infusion during upper limb surgeries by using monitored anesthesia care. Subjects and Methods: Sixty adult consenting patients of ASA physical status I to III of either gender were enrolled and brachial plexus block was established with $20 \mathrm{~mL}$ of $0.5 \%$ bupivacaine using ultrasound. Patients were randomized into two equal groups of 30 patients each to receive either dexmedetomidine $1 \mu \mathrm{g} / \mathrm{kg}$ over $10 \mathrm{~min}$, followed by maintenance fusion of $0.4 \mu \mathrm{g} / \mathrm{kg} / \mathrm{h}(\mathrm{Group} \mathrm{D})$ or propofol infusion of $75 \mu \mathrm{g} / \mathrm{kg} / \mathrm{min}$ over $10 \mathrm{~min}$, followed by $50 \mu \mathrm{g} / \mathrm{kg} / \mathrm{min}$ (Group P). Intraoperative sedation and duration of postoperative analgesia were primary objectives. The hemodynamic changes, respiratory depression, recovery from sedation or any adverse events were noted as secondary outcomes. Results: Ultrasound helped to observe the spread of local anesthetic agent at brachial plexus. The patients of propofol group had faster onset with early recovery from sedation but sedation in patients of dexmedetomidine was clinically better with statistically significant difference. Duration of postoperative analgesia was also significantly enhanced with dexmedetomidine infusion. In propofol group, the blood pressure and heart rate remained lower when compared to dexmedetomidine infusion. There was no episode of respiratory depression in any patient. Conclusion: Dexmedetomidine infusion was better due to its stable hemodynamic profile, better intraoperative sedation and enhanced duration of postoperative analgesia without respiratory depression during upper limb surgeries.

Keywords: Brachial plexus block, Dexmedetomidine, Monitored anaesthesia care, Propofol, Ultrasound guidance.

Corresponding Author: Dr Kumkum Gupta, Professor, Department of Anaesthesiology and Critical care, Subharti Medical College, Swami Vivekanand Subharti University, NH-58 Bye Pass Road, Meerut-UP, India.

Received: July 2019

Accepted: August 2019

\section{Introduction}

Supraclavicular brachial plexus block using ultrasound is an efficient regional anaesthetic technique for the upper limb surgeries as single injection of local anaesthetic drug is adequate to produce surgical anaesthesia. Ultrasound helps to detect the anatomical variants of brachial plexus and allows imaging of related anatomical structures and spread of local anaesthetic agent in appropriate tissue planes. ${ }^{[1]}$

Monitored anaesthesia care associates the sedation with regional anesthesia. The intravenous sedation is used to diminish the anxiety and apprehension of patients without obtunding the protective airway reflexes. The patient remains responsive to verbal commands and able to maintain the respiration independently. ${ }^{[2]}$ Several techniques of intravenous sedation are available with primary goals to achieve sedation while maintaining arousibility, cooperation, airway and hemodynamic stability. ${ }^{[3]}$ There is always a quest to find out a better drug which could be used during regional anaesthetic technique with negligible drawbacks. Current techniques for sedation include intravenous midazolam, opioid analgesics, $\alpha 2$-adrenergic agonist and propofol with their associated drawbacks and none is completely complication free. Several authors have successfully used the dexmedetomidine sedation for monitored anaesthesia care during orthopaedic, plastic, ophthalmic and dental surgeries because of it produces analgesia and sedation without any respiratory depression. ${ }^{[4,5]}$

Propofol is widely used as sedative-hypnotic drug with a rapid onset of action, short recovery time with its antiemetic and euphoric properties. Continuous infusion of propofol is 
used for sedation in combination with regional anaesthesia because of its easy titrability. ${ }^{[6,7]}$

This study compared the sedation of dexmedetomidine infusion versus propofol infusion for monitored anaesthesia care during upper limb surgeries performed under brachial plexus block using ultrasound.

\section{Subjects and Methods}

This prospective randomized study was approved by Institutional Ethical Committee and written informed consent was obtained from all enrolled patients. Sixty patients of both genders, aged 24 to 58 years with BMI less than 24 $\mathrm{kg} / \mathrm{m}^{2}$, belonging to American Society of Anaesthesiologists (ASA) physical status I to III and scheduled for elective upper limb surgery under brachial plexus block, were studied.

The pre-anaesthetic evaluation was done and patients with clinically significant deranged coagulation profile, infection at the block site, allergy to local anesthetics or study medications, pre-existing neuromuscular, cardiovascular, and hepatic diseases, endocrinal or metabolic disorders, inability to visualize the brachial plexus with ultrasound or refusal to technique, were excluded from the study. Any patients taking psychotropic medications or receiving any analgesic therapy that modifies the pain perception, were also excluded from this study.

Patients were admitted prior to the day of surgery and were given tab. alprazolam $0.5 \mathrm{mg}$ and tab. ranitidine $150 \mathrm{mg}$, the night before surgery. Nil per oral status of at least 6 hours was ensured on the day of surgery. On arrival to the operation theatre, intravenous access was secured and lactated Ringer solution was started at the rate of 6-8 $\mathrm{mL} / \mathrm{kg} / \mathrm{h}$. Multipara monitor was attached to monitor heart rate, non-invasive blood pressure, electrocardiogram (ECG) and peripheral oxygen saturation $\left(\mathrm{SpO}_{2}\right)$. Patients were informed to communicate about the perception of any pain or discomfort during surgery.

Brachial plexus block was performed using ultrasound (Sonosite Micromax portable ultrasound machine) with a 23gauge $40 \mathrm{~mm}$ short bevelled echogenic needle and a predetermined volume of $20 \mathrm{~mL}$ of $0.5 \%$ bupivacaine was given around the brachial plexus after negative aspiration.

After establishment of brachial plexus blockade, the patients were divided into two equal groups of 30 patients each, according to computer generated random number table. Patients of Group D were given a loading dose of dexmedetomidine $1 \mu \mathrm{g} / \mathrm{kg}$ over $10 \mathrm{~min}$, followed by a maintenance infusion of $0.4 \mu \mathrm{g} / \mathrm{kg} / \mathrm{h}$. Patients of Group P were given a loading dose of propofol at a rate of $75 \mu \mathrm{g} / \mathrm{kg} / \mathrm{min}$, over $10 \mathrm{~min}$, followed by a maintenance infusion $50 \mu \mathrm{g} / \mathrm{kg} / \mathrm{min}$. Dexmedetomidine and propofol infusion was prepared by one of the authors and administered by using syringe infusion pump. The infusion was stopped $10 \mathrm{~min}$ before completion of surgery. Intraoperatively, all patients were given oxygen at rate of $2 \mathrm{~L} / \mathrm{min}$ via nasal catheter.

The pinprick method was used to assess the onset of sensory block in the appropriate area, using a 3-point scale for pain (2- sharp pain, 1- blunt pain, 0- no pain). The onset time of sensory block was taken from the time after completion of the injection to first loss of pinprick sensation in any dermatome. The onset of motor block was taken after completion of the injection to first loss of motor power, assessed by hand grip and movement at the elbow, wrist and fingers.

Patients were assessed for onset of sensory and motor blockade every 5 minutes till patient was unable to move the arm, elbow and fingers. Duration of analgesia was defined as the time from onset of sensory block until the complete recovery of sensation which was assessed by visual analogue score (VAS) scale for pain.

Intra-operative arterial blood pressure, heart rate, and peripheral oxygen saturation were recorded at every $5 \mathrm{~min}$ interval and any incidence of hypotension, bradycardia, and fall in peripheral oxygen saturation or respiratory rate were noted and managed according to clinical protocol.

During the procedure, the study drug infusion rate was continued at a constant rate throughout the surgery and was not altered till a sedation score of three (RSS 3). The level of sedation was assed at every 5 min intervals after study drugs, using Ramsay Sedation Scale: 1- Patient is awake, anxious and agitated or restless, 2- Patient is co-operative, oriented and tranquil, 3- Patient responds to commands and asleep, 4Patient exhibits brisk response to stimulus, 5- Patient exhibits a sluggish response to stimulus, and 6- Patient exhibits no response. All sedation score were documented considering the time of start the study drug as zero.

Infusion was varied if respiratory rate was lesser than $8 \mathrm{bpm}$ or $\mathrm{SpO} 2<94 \%$, hemodynamic changes of bradycardia or hypotension. Hypotension $(\mathrm{SBP}<90 \mathrm{~mm} \mathrm{Hg})$ was treated with increasing the rate of lactate Ringer solution and mephenteramine $6 \mathrm{mg}$, if required and bradycardia $(\mathrm{HR}<60$ $\mathrm{bpm}$ ) with atropine $0.5 \mathrm{mg}$, with a reduction in the rate of study drug infusion.

The infusion was stopped $10 \mathrm{~min}$ before completion of surgery and duration of effective analgesia with recovery time from sedation were recorded for all the patients. Any nausea, vomiting, shivering, pruritus or any other adverse event during surgery were also noted.

\section{Statistical Analysis}

The sample size was calculated in consultation with statistician who computed that approximately 23patients should be included in each group to ensure the power of study $80 \%$ and alpha error of 0.05 with confidence limit of $95 \%$ to detect clinically significant difference of $20 \%$ in mean duration of postoperative analgesia between the groups. The final sample size of 60 patients was set for better validation of results.

The data are expressed as mean and standard deviation (SD) and results were analyzed using Stat Graphic Centurion for windows, (Stat point technologies INC, Warrenton, Virginia). The demographic data for the categorical variables were compared using chi-square test and analysis of variance. Block characteristics were compared using ANOVA. A p-value of $<0.05$ was considered to indicate statistical significance. 


\section{Results}

This study compared the clinical effects of dexmedetomidine infusion versus propofol infusion for monitored anaesthesia care during upper limb surgeries, performed under brachial plexus block. The study was successfully completed on all sixty patients. Standardized anaesthesia technique was used for all patients. The ultrasound helped to observe the spread of local anesthetic agent in the brachial plexus region. The surgical anaesthesia was effective and scheduled surgery of upper limb could be performed uneventfully in all patients.

The demographic data for age, sex, weight, BMI, American Society of Anaesthesiologist (ASA) physical status and duration of surgery were comparable between the groups and are summarized in [Table1]

\begin{tabular}{|c|c|c|c|}
\hline Parameters & Group D & Group P & p-value \\
\hline Age (years) & $36.3 \pm 9.14$ & $35.2 \pm 10.2$ & 0.67 \\
\hline Sex (M: F) & $21: 9$ & $19: 11$ & 0.38 \\
\hline Weight (kg) & $58.7 \pm 7.9$ & $61.4 \pm 5.7$ & 0.56 \\
\hline BMI $\left(\mathrm{kg} / \mathrm{m}^{2}\right)$ & $20.54 \pm 2.67$ & $21.25 \pm 2.13$ & 0.43 \\
\hline $\begin{array}{l}\text { ASA grade } \\
\text { (I/II/III) }\end{array}$ & $15 / 9 / 6$ & $13 / 12 / 5$ & 0.19 \\
\hline $\begin{array}{l}\text { Mean duration } \\
\text { of surgery (min) }\end{array}$ & $158.17 \pm 16$ & $156.35 \pm 12$ & 0.47 \\
\hline $\begin{array}{l}\text { Mean duration } \\
\text { of effective } \\
\text { analgesia (min) }\end{array}$ & $327.53 \pm 2.54$ & $296.47 \pm 3.14$ & $0.007 *$ \\
\hline $\begin{array}{l}\text { Mean recovery } \\
\text { time (min) }\end{array}$ & $27.06 \pm 2.26$ & $15.27 \pm 1.89$ & $0.04 *$ \\
\hline
\end{tabular}

The baseline mean heart rate, systemic blood pressure and oxygen saturation were comparable between both the groups. Seven patients of propofol group suffered from hypotension (SBP $<90 \mathrm{mmHg}$ ), which was managed by increasing the rate of lactate Ringer solution and by reducing the rate of propofol infusion. Bradycardia (heart rate $<60$ beats $/ \mathrm{min}$ ) occurred in five patients of dexmedetomidine group which was normalized by reducing the rate of dexmedetomidine infusion. None of the patient required vasopressor or atropine during study period. [Table 2]

The mean time required to achieve complete sensory block showed no statistically significant difference between the groups. The intensity of pain was significantly reduced by dexmedetomidine infusion in comparison to propofol infusion and the duration of effective analgesia was longer in patients of Group D $(327.53 \pm 2.54$ min versus $296.47 \pm 3.14$ min in Group P) with statistically significant difference between both the groups $(p=0.037)$. [Table 3]

Baseline sedation scores were comparable between the groups, but statistical significant difference in mean sedation score was observed at $5 \mathrm{~min}$ in patients of Group $\mathrm{P}$ and at 10 min in patients of Group D, which remained throughout the intraoperative period. Recovery time from sedation score of RSS 3 was significantly prolonged in patients of Group D when compared to Group P ( $\mathrm{p}<0.001)$.

The respiratory rate and peripheral oxygen saturation were comparable between the groups. None of the patients complained of difficulty in breathing or showed clinical evidence of respiratory depression. There were no surgical or anaesthetic complications. No side effects of nausea, vomiting, or pruritus were observed in any patient. Postoperatively, there was no recall of intra-operative events in any patient. All patients were awake, able to obey commands and could walk without difficulty. [Table - 4]

\begin{tabular}{|c|c|c|c|c|c|c|}
\hline $\begin{array}{l}\text { Parame } \\
\text { ters }\end{array}$ & $\begin{array}{l}\text { Heart } \\
\text { rate } \\
\text { (beats/ } \\
\text { min) }\end{array}$ & $\begin{array}{l}\text { Heart } \\
\text { rate } \\
\text { (beats/ } \\
\text { min) }\end{array}$ & & $\begin{array}{l}\text { SBP } \\
(\mathbf{m m} \\
\mathbf{H g})\end{array}$ & $\begin{array}{l}\text { SBP } \\
(\mathbf{m m} \\
\mathbf{H g})\end{array}$ & \\
\hline Groups & $\mathrm{D}$ & $P$ & $\begin{array}{l}\text { p- } \\
\text { val } \\
\text { ue }\end{array}$ & $\mathrm{P}$ & $\mathrm{D}$ & $\begin{array}{l}\text { p- } \\
\text { val } \\
\text { ue }\end{array}$ \\
\hline $\begin{array}{l}\text { Pre- } \\
\text { operati } \\
\text { ve }\end{array}$ & $\begin{array}{l}73.62 \pm \\
10.7\end{array}$ & $\begin{array}{l}76.42 \pm \\
11.5\end{array}$ & $\begin{array}{l}0.4 \\
1\end{array}$ & $\begin{array}{l}132.70 \pm \\
17.31\end{array}$ & $\begin{array}{l}136.32 \pm \\
11.5\end{array}$ & $\begin{array}{l}0.6 \\
8\end{array}$ \\
\hline $\begin{array}{l}\text { 5min } \\
\text { after } \\
\text { study } \\
\text { drug } \\
\text { infusio } \\
\text { n }\end{array}$ & $\begin{array}{l}62.29 \pm \\
11.5\end{array}$ & $\begin{array}{l}68.47 \pm \\
11.3\end{array}$ & $\begin{array}{l}0.6 \\
8\end{array}$ & $\begin{array}{l}124.27 \pm \\
7.8\end{array}$ & $\begin{array}{l}126.45 \pm \\
6.96\end{array}$ & $\begin{array}{l}0.4 \\
9\end{array}$ \\
\hline $10 \mathrm{~min}$ & $\begin{array}{l}84.41 \pm \\
6.8\end{array}$ & $\begin{array}{l}72.8 \pm 9 . \\
3\end{array}$ & $\begin{array}{l}0.5 \\
9\end{array}$ & $\begin{array}{l}118.76 \pm \\
5.36\end{array}$ & $\begin{array}{l}121.75 \pm \\
3.89\end{array}$ & $\begin{array}{l}0.5 \\
7\end{array}$ \\
\hline $15 \mathrm{~min}$ & $\begin{array}{l}74.63 \pm \\
10.6\end{array}$ & $\begin{array}{l}80.2 \pm 8 . \\
8\end{array}$ & $\begin{array}{l}0.6 \\
1\end{array}$ & $\begin{array}{l}112.63 \pm \\
2.71\end{array}$ & $\begin{array}{l}112.77 \pm \\
4.27\end{array}$ & $\begin{array}{l}0.6 \\
3\end{array}$ \\
\hline $30 \mathrm{~min}$ & $\begin{array}{l}59.74 \pm \\
9.3\end{array}$ & $\begin{array}{l}66.74 \pm \\
9.3\end{array}$ & $\begin{array}{l}0.0 \\
3^{*}\end{array}$ & $\begin{array}{l}113.21 \pm \\
1.47\end{array}$ & $\begin{array}{l}96.36 \pm 1 \\
0.53\end{array}$ & $\begin{array}{l}0.0 \\
1^{*}\end{array}$ \\
\hline $45 \mathrm{~min}$ & $\begin{array}{l}62.82 \pm \\
9.6\end{array}$ & $\begin{array}{l}68.72 \pm \\
8.5\end{array}$ & $\begin{array}{l}0.4 \\
7\end{array}$ & $\begin{array}{l}112.38 \pm \\
4.93\end{array}$ & $\begin{array}{l}103.07 \pm \\
5.64\end{array}$ & $\begin{array}{l}0.1 \\
5\end{array}$ \\
\hline $60 \mathrm{~min}$ & $\begin{array}{l}62.65 \pm \\
9.2 \\
\end{array}$ & $\begin{array}{l}69.62 \pm \\
8.4 \\
\end{array}$ & $\begin{array}{l}0.4 \\
9 \\
\end{array}$ & $\begin{array}{l}113.26 \pm \\
3.15 \\
\end{array}$ & $\begin{array}{l}110.19 \pm \\
2.71 \\
\end{array}$ & $\begin{array}{l}0.8 \\
1 \\
\end{array}$ \\
\hline $75 \mathrm{~min}$ & $\begin{array}{l}67.32 \pm \\
10.4\end{array}$ & $\begin{array}{l}72.57 \pm \\
12.3\end{array}$ & $\begin{array}{l}0.7 \\
9\end{array}$ & $\begin{array}{l}114.41 \pm \\
2.9\end{array}$ & $\begin{array}{l}115.11 \pm \\
1.35\end{array}$ & $\begin{array}{l}0.8 \\
3\end{array}$ \\
\hline $90 \mathrm{~min}$ & $\begin{array}{l}65.41 \pm \\
12.7\end{array}$ & $\begin{array}{l}78.24 \pm \\
1.4\end{array}$ & $\begin{array}{l}0.6 \\
7\end{array}$ & $\begin{array}{l}113.69 \pm \\
6.33\end{array}$ & $\begin{array}{l}107.64 \pm \\
5.47\end{array}$ & $\begin{array}{l}0.3 \\
7\end{array}$ \\
\hline
\end{tabular}

\begin{tabular}{|c|c|c|c|}
\hline Parameter/Groups & Group D & Group P & P-value \\
\hline $\begin{array}{l}\text { Onset time of } \\
\text { sensory block (min) }\end{array}$ & $10.36 \pm 1.7$ & $9.57 \pm 1.5$ & 0.65 \\
\hline $\begin{array}{l}\text { Onset of motor } \\
\text { block (min) }\end{array}$ & $\begin{array}{l}11.10 \pm \\
1.24\end{array}$ & $\begin{array}{l}10.46 \pm \\
1.30\end{array}$ & 0.46 \\
\hline $\begin{array}{l}\text { Complete sensory } \\
\text { block (min) }\end{array}$ & $\begin{array}{l}14.72 \pm \\
9.18\end{array}$ & $\begin{array}{l}15.67 \pm \\
12.58\end{array}$ & 0.74 \\
\hline $\begin{array}{l}\text { Duration of motor } \\
\text { block (min) }\end{array}$ & $226.58 \pm 41$ & $215.12 \pm 30$ & 0.091 \\
\hline $\begin{array}{l}\text { Duration of sensory } \\
\text { analgesia (min) }\end{array}$ & $327.53 \pm 24$ & $296.47 \pm 34$ & $0.037 *$ \\
\hline VAS score at $4 \mathrm{hr}$ & 3 & 3 & 0 \\
\hline
\end{tabular}

\section{Discussion}

Surgical anaesthesia renders the patient insensible to noxious surgical stimulation and is the result of the interaction of hypnotics and analgesics in synergistic manner. The hypnotic component is produced by the administration of intravenous anaesthetics, whereas the analgesic component is created by either opioid analgesics or local anesthetics (regional anesthesia). Some drugs such as ether, nitrous oxide, ketamine and $\alpha-2$ agonists provide both hypnotic and 
analgesic components to some degree.

Monitored anaesthesia care combines sedative/hypnotics with regional anaesthesia to provide analgesia with sedation and allowing the patient to maintain his airway. Ultrasound guidance to establish brachial plexus block, is preferred due to improve success rate and minimal risks of intra-arterial injection or a pneumothorax.

Table 4: Properties, complications and adverse events of dexmedetomidine and propofol infusion

\begin{tabular}{|l|l|l|}
\hline $\begin{array}{l}\text { Properties / } \\
\text { Complications }\end{array}$ & Dexmedetomidine & Propofol \\
\hline Pain on IV injection & No & Present \\
\hline $\begin{array}{l}\text { Analgesia in sub- } \\
\text { hypnotic dosages }\end{array}$ & Yes & Minimal \\
\hline $\begin{array}{l}\text { Amnesia in sub- } \\
\text { hypnotic dosages }\end{array}$ & Present & Negligible \\
\hline $\begin{array}{l}\text { Time of onset of } \\
\text { sedation after } \\
\text { intravenous infusion }\end{array}$ & $5-10$ min & $\begin{array}{l}\text { Quick (within } \\
\text { 1min) }\end{array}$ \\
\hline $\begin{array}{l}\text { Potential for } \\
\text { significant } \\
\text { bradycardia }\end{array}$ & Seen in 5 patients & $\begin{array}{l}\text { None of the } \\
\text { patient }\end{array}$ \\
\hline $\begin{array}{l}\text { Potential for } \\
\text { significant } \\
\text { hypotension }\end{array}$ & Minimal (none) & $\begin{array}{l}\text { Occurred in } \\
7 p a t i e n t s\end{array}$ \\
\hline
\end{tabular}

The intravenous sedation is associated with respiratory depression, lack of orientation, hypotension and delayed gastrointestinal motility. Use of alpha 2 adrenoreceptor agonists as adjuvant to local anaesthetics agents in peripheral nerve blocks improved the quality of anaesthesia and prolonged the duration of analgesia. Yoshitomi et al found that addition of clonidine or dexmedetomidine to lignocaine enhances local analgesic effect. ${ }^{[8]}$

This study has compared the intraoperative sedation of dexmedetomidine with propofol infusion during upper limb surgeries, because propofol is used commonly in past for monitored anesthesia care due to its favourable pharmacokinetic profile of sedative-hypnotic. ${ }^{[9]}$

Continuous infusion of short acting drug is superior to intermittent bolus dosing as it produces less fluctuation in drug concentration and also reduces the total amount of drug. Drugs infusion rate can be titrated according to noxious stimuli to avoid excessive sedation. Low dose infusion of propofol or a short acting barbiturate is appropriate for sedation in conjunction with regional anesthesia. Midazolam (1-2 mg) with or without fentanyl (12.5-25 $\mu \mathrm{g})$ or sufentanil $(2.5-5 \mu \mathrm{g})$ is also a common regimen. Dexmedetomidine acts on $\alpha-2$ adrenoreceptor as agonist in the dorsal horn of spinal cord, to produce analgesia and sedation. Its sedative effect is due to suppression of neuronal firing in the locus coeruleus to inhibit the norepinephrine release. ${ }^{[10]}$

The results of present study revealed that the onset of sensory and motor blocks of brachial plexus block were comparable between the groups. Dexmedetomidine infusion provided enhanced duration of block with postoperative analgesia.

The early onset time of sedation in the propofol group compared to dexmedetomidine group occurs because propofol is highly lipophilic and distributes rapidly into central nervous system. Patients of both groups showed adequate level of sedation but it was deeper with dexmedetomidine infusion, when compared to propofol infusion. This is in agreement with results of Arain et al ${ }^{[1]}$ and Kaya et al ${ }^{[12]}$. The mean recovery time from sedation was significantly prolonged in patients of dexmedetomidine group while shorter in propofol group. The results of our study correlates well with findings obtained by Abdelkareim et al. ${ }^{[13]}$

Arain et al concluded that the targeted sedation could be achieved more rapidly with propofol while onset and offset of sedation with dexmedetomidine was slower when compared with propofol. Dexmedetomidine sedation was associated with improved analgesia and less opioid consumption in postoperative period. They found no differences in psychomotor performance and respiratory rate between the groups. ${ }^{[11]}$

Shah et al compared the intravenous dexmedetomidine versus propofol for intraoperative sedation during spinal anaesthesia and stated that onset and offset from sedation was earlier with propofol, but patient's satisfaction was better with dexmedetomidine. They concluded that dexmedetomidine could be a valuable adjuvant for intraoperative sedation during spinal anesthesia. ${ }^{[14]}$

In this study, the duration of analgesia was enhanced with dexmedetomidine when compared to propofol with statistically significant difference. Dexmedetomidine produces analgesia by binding to adrenoreceptors in the spinal cord. Jorm and Stamford, observed that dexmedetomidine inhibits the locus coeruleus of brain stem which could explain the prolongation of analgesia after dexmedetomidine infusion. ${ }^{[15]} \mathrm{Al}-\mathrm{Mustafa}$ et al also concluded that spinal anaesthesia could be prolonged by intraoperative dexmedetomidine infusion, with good sedation and hemodynamic stability. ${ }^{[16]}$ This study also observed the prolonged duration of sensory analgesia in dexmedetomidine group as compared to propofol group.

Tripathi A et al compared the clonidine and dexmedetomidine as an adjuvant to bupivacaine for brachial plexus blockade and concluded that dexmedetomidine enhances the duration of brachial plexus blockade and could improve the quality of analgesia. ${ }^{[17]}$

In this study, intraoperative mean heart rate and blood pressure were significantly remained lower in patients of propofol group. The episode of hypotension was observed in seven patients of propofol group due to direct inhibitory effect of propofol on sympathetic outflows causing peripheral vasodilation, which was managed by rapid infusion of crystalloid solution only.

Dexmedetomidine also decreases the sympathetic outflow and serum levels of circulating catecholamine, thus decreases the blood pressure, as observed by Kaygusuz et al ${ }^{[18]}$ during shockwave lithotripsy. The episode of bradycardia was observed in five patients of dexmedetomidine group because of its sympatholytic properties and vagal mimetic effects which was managed by reducing the rate of dexmedetomidine infusion. This study also showed the same results.

Both propofol and dexmedetomidine are known to show minimal respiratory depression. Though studies have reported minimal to no respiratory depression after dexmedetomidine or clonidine, as their action is not mediated by $\gamma$-amino-butyric acid (GABA)-mimetic system, 
hence it does not depress the respiratory drive during sedation. ${ }^{[19]}$ In the present study, respiratory depression was not recorded in any patients and respiratory rate remained within acceptable limits throughout the study period in all patients.

Kumari $\mathrm{R}$ et al stated that dexmedetomidine provides excellent sedation during surgery and sedation scores reach normal within 15 min after stopping the drug. ${ }^{[20]}$ Verma $\mathrm{R}$ et al concluded that dexmedetomidine seems to be better for monitored anesthesia care with hemodynamic stability when compared to propofol. The results of present study are in consistent with these studies. ${ }^{[21]}$

Awareness and post-operative recall of events during anesthesia is an important clinical problem. Drugs with sedative-hypnotic properties reduce attention to stimuli as a direct consequence of depression of consciousness. [22] Dexmedetomidine and propofol, both have amnesic effects at sub-hypnotic doses. None of the patients of the present study could recall intra-operative events. These results of present study are in accordance with the study done by Ramsay and co-workers. ${ }^{[5]}$

\section{Conclusion}

Both dexmedetomidine and propofol infusions produced adequate level of sedation, but dexmedetomidine could also enhance the duration of postoperative analgesia of brachial plexus block. Use of ultrasound has facilitated the accurate perineural placement of local anesthetic agent and reduced its complication rates. This study concluded that dexmedetomidine could be better than propofol for monitored anesthesia care during upper limb surgeries.

\section{References}

1. Neal JH. Ultrasound guided regional anesthesia and patient safety: an evidence based analysis. Reg Anesth Pain Med2010; 35: 559-67.

2. American Society of Anesthesiologists. Distinguishing monitored anesthesia care (MAC) from moderate sedation/ analgesia (Conscious sedation). www.asahq. Org 2009.

3. Green SM. Research advances in procedural sedation and analgesia. Ann Emerg Med2007; 49: 31-6.

4. Ekstein M, Gavish D, Ezri T, Weinbroum AA. Monitored anesthesia care in the elderly: Guidelines and recommendations. Drugs Aging2008; 25: 477-500.

5. Ramsay MA and Luterman DL. Dexmedetomidine as a total intravenous anesthetic agent. Anesthesiology2004; 101: 787-90.

6. Duggan E, El Beheiry H, Perlas A, Lupus M, Nuica A, Chan VW,
Brull R. Minimum effective volume of local anesthetic for ultrasound guided supraclavicular brachial plexus block. Reg Anesth Pain Med2009; 34: 215-8.

7. Marik PE. Propofol: therapeutic indications and side effects. Curr Pharm Des 2004; 10: 3639-49.

8. Yoshitomi T, Kohjitani A, Maeda S, Higuchi H, Shimada M, Miyawaki T. Dexmedetomidine enhances the local anesthetic action of lidocaine via alpha-2A adrenoceptor. Anesth Analg 2008; 107: 96101

9. Smith I, Monk TG, White PF and Ding I. Propofol infusion during regional anesthesia. Anesth Analg 1994; 79: 313-9.

10. Gabriel JS, Gordin V. Alpha 2 agonists in regional anesthesia and analgesia. Curr Opin Anaesthesiol 2001; 14: 751-3.

11. Arain SR and Ebert TJ. The efficacy, side effects and recovery characteristics of dexmedetomidine versus propofol when used for intraoperative sedation. AnesthAnalg2002; 95: 461-6.

12. Kaya FN, Yavascaoglu B, Turker G, Yildirin A, Gurber A, Mogol EB. Intravenous dexmedetomidine, but not midazolam, prolongs bupivacaine spinal anesthesia. Can J Anaesth 2010; 57: 39-45.

13. Abdelkarein S, Mamoud M, Jihad M, Diana F, Mohammad Q, Subhi $\mathrm{M}$ et al. Intravenous dexmedetomidine or propofol adjuvant to spinal anesthesia in total knee replacement surgery. J Med J 2011; 45: 174183

14. Shah PJ, Dubey KP, Sahare KK, Agarwal A. Intravenous dexmedetomidine versus propofol for intraoperative moderate sedation during spinal anesthesia: A comparative study. J Anesthesiol Clin Pharmacol 2016; 32: 245-9.

15. Jorm CM, Stamford JA. Actions of the hypnotic anesthetic, dexmedetomidine, on noradrenaline release and cell firing in rat locus coeruleus. Br J Anaesth 1993; 71: 447-9.

16. Al-Mustafa MM, Badran IZ, Abu-Ali HM, Al-Barazangi BA, Massad IM. Al- Ghanem. Intravenous dexmedetomidine prolongs bupivacaine spinal analgesia. Middle East J Anesthesiol 2009; 20: 225-31.

17. Tripathi A, Sharma K, Somvanshi M, Samal RL. A comparative study of clonidine and dexmedetomidine as an adjuvant to bupivacaine in supraclavicular brachial plexus block. J Anesthesiol Clin Pharma 2016; 32: 344-8.

18. Kaygusuz K, Gokce G, Gursoy S, Ayan, Mimaroglu C Gultekin Y. A comparison of sedation with Dexmedetomidine or Propofol during Shockwave Lithotripsy: A randomized controlled trial. Anesth Analg 2008; 106: 114-9.

19. Marhofer D, Kettner SC, Marhofer P, Piles S, Weber M, Zeitlinger M. Dexmedetomidine as an adjuvant to ropivacaine prolongs peripheral nerve block: A volunteer study. Br J Anaesth2013; 110: 438-42.

20. Kumari R, Kumar A, Kumar S. Singh R. Intravenous dexmedetomidine as an adjuvant to subarachnoid block: A simple effective method of better perioperative efficacy. J Anesthesiol Clin Pharmacol 2017; 33: 203-8.

21. Verma R, Gupta R, Bhatia K, Bogra J, Agarwal SP. Dexmedetomidine and propofol for monitored anesthesia care in the middle ear surgery. Indian J Otol 014, 20: 70-4.

22. Hogue CW, Talke P, Stein PK, Richardson C, Domitrovich PP, Sessler DI. Autonomic nervous system responses during sedation infusion of dexmedetomidine. Anaesthesiology 200; 97: 592-8.

Copyright: () the author(s), publisher. Academia Anesthesiologica International is an Official Publication of "Society for Health Care \& Research Development". It is an open-access article distributed under the terms of the Creative Commons Attribution Non-Commercial License, which permits unrestricted non-commercial use, distribution, and reproduction in any medium, provided the original work is properly cited.

How to cite this article: Gupta K, Gupta P K, Agrawal S, Kumar A, Karla P, Gupta K. Upper Limb Surgeries under Brachial Plexus Block Using Infusion of Dexmedetomidine or Propofol for Monitored Anaesthesia Care - A Comparative Study.Acad. Anesthesiol. Int. 2019;4(2):159-63.

DOI: dx.doi.org/10.21276/aan.2019.4.2.36

Source of Support: Nil, Conflict of Interest: None declared. 